\title{
Addressing Xenophobia in the Equality Courts of South Africa
}

\author{
JUSTIN DE JAGER
}

\begin{abstract}
South African society bears a legacy of inequality and struggle against oppression. In the Constitutional era, our courts have held that the right to equality is a core fundamental value against which all law and state practice must be tested. South Africa's Equality Courts have been heralded as a transformative mechanism for the redressing of systemic inequality and the promotion of the right to equality. Following the aftermath of the 2008 xenophobic attacks in South Africa, the University of Cape Town Refugee Law Clinic, on behalf of some of the victims of these attacks, launched equality claims against the South African Police Services in order to address the unfair discrimination and xenophobia of police officials in protecting these victims. This paper reviews the two matters launched by the Clinic in the Equality Courts, examining the challenges that effectively reduce the accessibility of the Equality Courts and the difficulty inherent in proving discrimination in equality claims, and commenting on the benefits of using these courts to address xenophobia.
\end{abstract}

\section{Résumé}

La société sud-africaine porte un héritage d'inégalité et de lutte contre l'oppression. Dans la période constitutionnelle, nos tribunaux ont statué que le droit à l'égalité était une valeur fondamentale, à la mesure de la quelle toute loi et pratique d'État doit être testée. Les Tribunaux de l'Égalité d'Afrique du Sud ont été salués en tant que mécanisme de transformation et de redressement des inégalités systémiques, et de la promotion du droit à l'égalité. Suite aux conséquences des attaques xénophobes de 2008 en Afrique du Sud, la Clinique du Droit des Réfugiés de la University of Cape Town a lancé, au nom de certaines victimes de ces attaques, des revendications d'égalité à l'endroit des services de police sud-africains, dans le but de soulever le problème de l'attitude discriminatoire et xénophobe des officiers de police lors de la protection des victimes. Cet article examine les deux causes présentées par la Clinique aux Tribunaux de l'Égalité, les facteurs réduisant l'accès aux Tribunaux de l'Égalité, les difficultés de prouver la discrimination dans les revendications d'égalité, et évalue l'utilité de faire appel à ces tribunaux en matière de xénophobie.

\section{Introduction}

Historically, South Africa operated a tightly controlled "closed-border" policy with regards to the vast majority of migrants. ${ }^{1}$ However, after the first democratic elections in 1994 the country opened up internationally and became a party to a number of important human rights instruments, including the United Nations (UN) Convention Relating to the Status of Refugees ${ }^{2}$ and the Organization of African Unity (OAU) Convention Governing Specific Aspects of Refuge Problems in Africa. ${ }^{3}$ In doing so South Africa affirmed its commitment to receive and protect individuals in need of care due to persecution or hostilities in their home countries.

Following this shift in policy and practice towards a human rights orientated migratory regime, an increased inflow of migrants into South Africa .became evident. ${ }^{4}$ Regrettably, however, violence against foreign nationals has been an ongoing element of post-Apartheid South Africa. ${ }^{5}$ In March 1998, only four years into the constitutional democratic era, a Human Rights Watch report on the situation in South Africa confirmed that:

Since the 1994 elections, South Africa has seen a rising level of xenophobia. As in many other countries, immigrants have been 
blamed for a rise in violent crime, drug dealing and a rise in drug abuse, unemployment, and other social ills. Immigrants from African countries have been the target of attacks, often because they are perceived as being in direct competition with South Africans for jobs or services. In addition, African immigrants are often the target of random violence and robbery, as criminals perceive them as easy targets because they are unlikely to go to the police. The police and Home Affairs officials have shared this antagonism toward foreigners. The generally negative attitude toward foreigners encourages and condones abuses by police, army, and Home Affairs officials not only against those suspected of being undocumented migrants, but also against non-South Africans who are lawfully in the country, who can expect little or no help from the police when they themselves are victims of crime, including violent assault and theft. ${ }^{6}$

The UN High Commissioner for Refugees has recently reported that xenophobia in South Africa undermines refugees' local integration and the stability of their livelihoods, often compelling individuals to reside in more expensive inner-city areas for fear of attacks in the townships. ${ }^{7}$ An analysis of the reference to foreigners in the print media conducted by the Southern African Migration Project in 2000 found that a shocking fifty-six percent of press articles referring to foreign nationals contained at least one negative reference and twenty percent contained four or more. ${ }^{8}$ These reports demonstrate the insidious nature of xenophobic attitudes in South African society.

In 2008, xenophobia in South Africa reached new heights, as large waves of violent attacks swept across the country, ${ }^{9}$ almost infectiously, leaving sixty-two people dead, 670 wounded, many women raped, over 100000 people displaced and property worth millions looted, destroyed or seized. ${ }^{10}$

In the aftermath of the attacks the University of Cape Town (UCT) Refugee Law Clinic (hereafter "the Clinic"), which has been providing free legal assistance to refugees ${ }^{11}$ throughout Cape Town since 1998, was approached by a number of victims of the attacks. In addition to reporting the loss of their possessions to looters, the individuals reported police officials' refusal to assist them in protecting their property.

The Clinic formulated a response to these allegations that led to the institution of legal proceedings in the Western Cape High Court, sitting as the Equality Court, for an action of vicarious liability against the Minister of Safety and Security on the basis that the members of the South African Police Services (hereafter "the police") exercised their function during the xenophobic attacks in a discriminatory manner and failed to provide adequate protection to the Complainants due to their nationality.
The purpose of this paper is to explore in more detail two of these cases: Said and others $v$ the Minister of Safety and Security ("the Said matter"), 12 and Osman v Minister of Safety \& Security ("the Osman matter"). ${ }^{13}$ While the Osman matter has been finalised, the Said matter is currently pending leave to appeal. One of the objectives of the Clinic in bringing these cases was to test the Equality Courts as a forum for combating xenophobia. The aim was not simply to seek ordinary civil damages but to utilise the wide powers of these special courts to attempt to root out the ingrained xenophobia within the police officials.

Structurally, this paper will commence by outlining the direct link, which the Clinic observed between xenophobia and its clients' right to equality. Phrased conversely, a xenophobic mindset resulted in the discriminatory provision of services by the police to the refugee victims of the xenophobic attacks. The second section will consider the Equality Courts and the perceived advantages, which led the Clinic to institute the proceedings in that particular forum. The third section will then discuss the Said and Osman matters, outlining the experiences of the Clinic during the litigation process. Finally, this paper will discuss some of the challenges which were experienced during the litigation process in the Equality Courts.

Given the prevalence of xenophobia in South African society, creative measures are necessary to address this problem. One such mechanism is legal accountability through the promotion of access to justice, which entails perpetrators being brought before the courts and affords the victims a forum to have their voices heard. It was the opinion of the Clinic that the objectives and structure of the Equality Courts represented the best forum for this purpose.

\section{Xenophobia and the Violation of the Right to Equality}

In order to have the Said and Osman matters heard in the Equality Courts, as the Clinic set out to do, it was necessary to ground the cause of action within the ambit of the Promotion of Access to Equality and Prevention of Unfair Discrimination Act. ${ }^{14}$ What this entailed was establishing a clear link between xenophobia and the clients' right to equality.

The dictionary definition of xenophobia is an 'extreme fear or dislike of people from other countries'. ${ }^{15}$ However, the term is more commonly used to denote a hatred of foreigners characterised by a negative attitude towards such individuals. ${ }^{16}$

In his obiter dictum, Sachs J in his minority judgement in the Union of Refugee Women $v$ the Director: Private Security Industry Regulatory Authority17 held that such prejudice was prevalent in South Africa and that it struck at the heart 
of our Constitution. ${ }^{18}$ Justice Sachs went on to note that the purpose of refugee law is to overcome experiences of trauma and displacement. Adverse treatment in the host country would defeat this objective and induce an experience of alienation and helplessness. ${ }^{19}$ Kondile AJ, writing for the majority of the Constitutional Court, confirmed that refugees, by virtue of the fact that they have been compelled to flee their homes for fear of persecution, constitute a vulnerable group in our society. ${ }^{20}$ Consequently, discrimination against refugees constitutes discrimination against a vulnerable group and impairs their rights in a serious manner. ${ }^{21}$

In the leading case on state liability for police negligence, Minister of Safety and Security $v$ Carmichele, 22 the Supreme Court of Appeal held that police officers are liable for their failure to perform their statutory and constitutional duties. $^{23}$

It was the case of the Clinic in the Said and Osman matters that the police had discriminated against the victims of the xenophobic attacks on the basis of their nationality. As a vulnerable group the police owed a statutory and constitutional duty of care to the individuals and had those individuals not been foreigners the police would have exercised their function differently. In this way, it was the argument of the Clinic that the litigants were the victims of discrimination, which had infringed their rights to equality and dignity resulting in both constitutional and general damages.

In essence, the deeply ingrained xenophobic attitude of the police officers, who were charged with quelling the xenophobic attacks, adversely affected the exercise of their function. However, eradicating such a manifestation of xenophobia requires more than a simple damages claim paid by the state. Rather, it requires a reshaping of the perspectives of the police officers on the ground. For this reason the Clinic identified the Equality Courts as a forum for attempting to address the problem.

\section{The Equality Courts}

In 2000, the Promotion of Equality and Prevention of Unfair Discrimination Act ("the Equality Act") 24 was passed with the intention that it would be the key legislative tool for the enforcement and promotion of the right to equality. ${ }^{25}$ The drafters of the Equality Act sought to achieve this end by providing victims of unfair discrimination, hate speech and harassment with a forum to provide access to justice and an effective remedy. ${ }^{26}$ Although the main impetus for the creation of the Equality Act was likely addressing the inequalities of South Africa's Apartheid era, ${ }^{27}$ Section One of the Act expressly includes "nationality" among the prohibited grounds of discrimination and defines nationality as "ethnic or national origin and includes practices associated with xenophobia and other adverse assumptions of a discriminatory nature." 28

The Act designates all Magistrate Courts and High Courts as Equality Courts for their area of jurisdiction. ${ }^{29}$ In doing so the intention is not to extend jurisdiction to the courts to hear equality matters in their normal capacity, but rather to create special Equality Courts for the various areas, which would be staffed by trained judicial officers and administrative clerks. ${ }^{30}$

Training of staff in the nuances of the Equality Act and in equality jurisprudence plays an important part in the Equality Court's divergence from the normal practice adopted in South African courts. The Equality Act Regulations ${ }^{31}$ expressly require the judicial officer to ascertain the relevant facts and question the parties and witnesses. ${ }^{32}$ For Albertyn et al.33 this active involvement of the judicial officer could assist in the creation of an accessible, informal and participatory proceeding, levelling the playing field in the case where a disadvantaged party may not have the resources to obtain skilled lawyers. ${ }^{34}$ This model is more akin to an inquisitorial structure as opposed to the adversarial system upon which the South African legal system is currently based and as such judicial officers may not be accustomed to relinquishing their customary role as a "neutral umpire."

Within the context of this inquisitorial court structure the Equality Courts are intended to be public spaces which allow for the proliferation of different voices, previously denied under apartheid South Africa. ${ }^{35}$ In this way the Equality Courts are not merely special rooms for dealing with equality matters but a transformative tool for bringing about greater justice for all. ${ }^{36}$ This notion of the courts as a "public space" was first proposed by Bohler-Muller in 2000. ${ }^{37}$ She suggests that the transformative jurisprudence of equality requires that individuals not be seen as independent rights-bearing entities but rather within a contextual reality. ${ }^{38}$ For Bohler-Muller the "ethic of care," as she explains dictates that competing interests be weighed and that conclusions be reached which are the least harmful to the most vulnerable party. ${ }^{39}$ Effectively, the challenge for Equality Courts is not to simply address each case mechanically, but rather to contextualise the cause of action so as to tailor a remedy which addresses not only the discrimination in question but rather goes to the root of the problem, addressing societal discriminatory structures. In doing so the courts are the guardians, of sorts, for vulnerable categories of individuals. The Bench Book for Equality Courts, 40 which is the text developed as the training programme for judicial officers, requires that presiding officers take account of the differences among South Africans so as to ensure fair and just decision making in the challenging area of Equality. ${ }^{41}$ 
This requires a comprehensive approach to social context education, despite such training being a complex task. ${ }^{42}$ Nevertheless, proper contextual judging must be seen as a powerful and effective way to ensure a move towards substantive equality and supports the independence and credibility of the judiciary. ${ }^{43}$

This "public space" where Complainants are permitted to have their grievances heard by an adjudicator trained to view the incident through a socially conscious lens attracted the Clinic to the Equality Courts. It was felt that given the vulnerable place of refugees in society, and the harm they suffered, the cases had to be handled with due care by an adjudicator with the proper mindset.

The other key dimension of the Equality Court which drew the Clinic to the forum was the extensive powers with which these courts are vested. Section 21 of the Equality Act confers wide power on the court in order to address both individual and systemic forms of inequality. ${ }^{44}$ Albertyn et al. suggest systematic violations of equality are not solved by individual court orders, rather the Equality Courts are required to provide relief which addresses the underlying causes of discrimination and seeks to reform the social attitudes, structures and institutions. ${ }^{45}$

In addition to the normal court remedies, Section 21 permits the court to make the following forms of orders: damages in respect of the impairment of dignity, pain and suffering, emotional and psychological suffering; ${ }^{46}$ damages in the form of an award to an appropriate body or organisation; ${ }^{47}$ availability of specific opportunities and privileges unfairly denied; ${ }^{48}$ Special measures for the addressing of the unfair discrimination; ${ }^{49}$ an unconditional apology; ${ }^{50}$ an appropriate deterrent; 51 and, an order to comply with any provision of the Act. ${ }^{52}$ Section 21 further permits the court the power to enforce these remedies through an internal audit of the respondent ${ }^{53}$ and a structural interdict requiring the respondent to make regular progress reports. ${ }^{54}$

Albertyn et al. suggest that the novelty of these remedies coupled with the complexity of equality matters require presiding officers to be given the skills and resources necessary to engage creatively with these remedies. ${ }^{55}$ The jurisprudence seems to suggest that many of the courts have indeed done so to some extent. In Strydom $v$ Nederduitse Gereformeerde Gemeente Moreleta Park, ${ }^{56}$ a case in which a teacher had been dismissed by the respondents on the basis of his sexual orientation and refusal to submit to a "cure" for his homosexuality, the court utilised both the damages provisions of the Equality Act, and further ordered remedies in the form of an unconditional apology. Likewise, in Sonke Gender Justice Network $v$ Malema ${ }^{57}$ the court ordered that Mr. Malema, a prominent political figure in South Africa, make a public apology, by way of press release, and pay damages to an appropriate institution. ${ }^{58}$ The Judge even found it fit to offer Mr. Malema some words of wisdom in relation to his place as a public figure. ${ }^{59}$

In short, the Equality Courts have distinct advantages permitting the hearing of inherently sensitive matters in an informal and accessible forum where the courts are empowered to tailor effective remedies to, not only address the matter at hand, but the deeper societal issues for which the Act was intended to combat. For these reasons the Clinic approached the Equality Courts on behalf of a number of clients who had been victims of the 2008 xenophobic attacks. The aim was to not only seek justice for the individuals concerned but also to utilise the Equality Courts as a means to address the xenophobic prejudice held by the police officers who had discriminated against the Clinic's clients.

\section{The UCT Refugee Law Clinic Cases}

As a result of the chronology of events the Clinic first launched the Said matter, which was soon followed by the Osman matter. In order to keep the chronology of events clear this paper will discuss the two cases in the order in which they were instituted.

The cause of action in the Said matter preceded the main waves of xenophobic attacks, occurring over a two day period in March 2008. The main attacks then flared up in May 2008 in Johannesburg before spreading to Durban and eventually back to Cape Town ${ }^{60}$ where the litigant in the Osman matter was then affected.

The Said matter saw the rising up of the residents of the informal settlement of Zwelethemba, near the Karoo town of Worcester in the Western Cape. The shops and livelihood of refugees from Somalia, Ethiopia and the Democratic Republic of Congo were looted, and in most cases completely destroyed. The perpetrators were South African residents who were not only the neighbours of the migrant population in the settlement but also the patrons of the small businesses they ran. When the looters took to the street they armed themselves with weapons and shouted xenophobic slogans. It was common cause between the parties that police officers from Zwelethemba, Worcester and Paarl were present in Zwelethemba at the time of the looting.

It was the Complainants' case that the police discriminated both directly and indirectly against them in the exercise of their duties. It was first argued that the police actively refused to provide assistance to the Complainants, thereby discriminating against them by actively guarding the South African owned shops while refusing to provide this same assistance to the Complainants on the basis of their nationality.

The Complainants argued further that their position in South African society, as a vulnerable category of persons, ${ }^{61}$ 
dictated a higher degree of care. The failure to meet this standard amounts to "adverse effect" discrimination, which occurred irrespective of the intention of the police. ${ }^{62}$

The Complainants sought to invoke the broad powers conferred on the Equality Court, ${ }^{63}$ by seeking relief which is three fold: [1] damages; [2] an unconditional apology and public admission of acts of unfair discrimination; and [3] a structural interdict requiring the police to establish a training program aimed at instructing police officers throughout the Western Cape on providing services to refugees in a sensitive manner. The Complainants further requested that the structural interdict be implemented by the South African Human Rights Commission, which was joined to the proceedings as a third party. This combination of remedies was possible within the list of creative remedies which the Act empowers the court to order. It was felt that by utilising this unique mechanism it would be possible for the court to, not only come to the assistance of the destitute Complainants, but also to root out the discriminatory and xenophobic attitude, which lead to the harm which the Complainants suffered.

Despite numerous delays in the proceedings, some of which will be addressed in the next section of this paper, Justice Erasmus handed down a decision on December 8 , 2011. The court noted that refugees, as forced migrants, are unable to seek protection from their own governments and embassies and are therefore dependent upon the South African government. ${ }^{64}$ It was noted further that discrimination on the basis of ethnic and social origin are within the scope of the right to Equality. ${ }^{65}$ However, the court ultimately came to the conclusion that:

... [T]he balance of probabilities support the view that the police were in fact not given orders to guard either Foreign owned or South African Shops. The evidence suggest that this was a conscious decision taken, motivated primarily by lack of resources, and the primary goal of saving lives, and not discrimination. ${ }^{66}$

On this basis, the court found that the Complainants had failed to prove that the Respondents had discriminated against them. ${ }^{67}$ However, the judge expressed his concern that the matter could not be left there. ${ }^{68} \mathrm{He}$ noted that the police had failed to prevent the looting and when the Complainants attempted to give statements to the police there was a clear lack of sensitivity exhibited by the police. ${ }^{69}$ Quite rightly Judge Erasmus stated that:

I am of the view that the police's failings in the above respects can be at least partly explained by an acute lack of sensitivity on their part to the light of refugees, their particular vulnerability, given their history and the likelihood of being victims of multiple trauma. ${ }^{70}$

In order to address this concern, Justice Erasmus found that, sitting as the Equality Court, he was empowered by the Equality Act to order the South African Human Rights Commission to provide training to relevant stakeholders and monitor and assess the observance with the recommendations it had outlined in its interim report. ${ }^{71}$ The report, which was prepared by the Human Rights Commission in terms of the interim order of the court, recommended that the police make adequate resources available to the Zwelethemba police station, provide personnel with sensitivity training and the implementation of effective monitoring of human rights violations and xenophobic incidents. ${ }^{72}$ As laudable as this finding is, the Clinic remains convinced that the actions of the police were a manifestation of xenophobic attitudes held by the police, which resulted in the discrimination against the Complainants. The Clinic has therefore filed for leave to appeal in this matter and at the time of writing the matter remains sub judice.

Though launched after the Said matter, the Osman matter ran concurrently with the first case. By May 2008 the xenophobic attacks had returned to Cape Town and rose, resulting in the looting of the Complainant's shop in the informal settlement of Dunoon, near Milnerton in the Western Cape. The Complainant testified that he drove to the shop to find three police vans standing nearby, whilst the looters were still carrying goods out of his shop. He testified that he approached one of the police officers for assistance in removing the remaining goods from his shop. The police officer responded that they would only assist him if his employees were still in the shop, but they would not assist simply to remove goods. He was then instructed by the police to leave Dunoon as the situation was becoming more dangerous. The Complainant testified that he was gravely upset as he had seen his shop being destroyed whilst several heavily armed policemen merely looked on as though this was part of an "evening's entertainment". The Equality Court accepted that a case of discrimination had been made out and therefore the onus shifted to the Respondents. Nevertheless, the court ultimately dismissed the claim, finding that in the absence of further evidence to support the Complainant's version it could not make a determination on his allegations. ${ }^{73}$

What the Osman matter illustrates is the stringent burden placed on claimants to prove a prima facie case of discrimination in equality claims. Until this point has been reached, the presumption is that no rights violation has occurred. Discrimination is, however, notoriously difficult to prove, particularly in situations where there is no 
express discrimination but rather a more insidious attitude. As discussed above, the court held that where a prima facie case has been made out this must be weighed against the rebutting evidence adduced by the respondents, however, the Equality Act is not clear on whether the onus shifts conclusively or who bears the ultimate burden. ${ }^{74}$ However, this creates a "grey area," alluding to the possibility that a claimant retains some form of residual burden.

A similar shifting burden procedure is contained in the Labour Relations Act, ${ }^{75}$ which provides that an employee must prove the existence of a dismissal and then the onus shifts to the employer to either rebut the dismissal or to prove that the dismissal was nevertheless procedurally and substantively fair. ${ }^{76}$ In this way the legislature has reversed the general principle that a person who claims a legal entitlement bears the onus of proving the factual basis of that claim. ${ }^{77}$ However, within the context of a dismissal it has been established that an employee is still required to adduce evidence that proves the dismissal was unfair. The employee cannot simply rely on a lack of evidence from the employer as grounds for substantiating a blank statement of unfairness. ${ }^{78}$ In the same way the finding of Davis J in the Osman matter can be seen as a requirement that the claimants adduce evidence to support the allegation of discrimination rather than simply relying on the respondents' failure to rebut the claimant's prima facie case. The difficulty with this is, however, linked to the problems with proving discrimination. The effects may be severe but the proof thereof may be all but impossible and therefore the rights violation may go unchecked.

\section{The Challenges Faced in the Equality Courts}

Unfortunately, during the course of the proceedings a number of the challenges documented by other authors, which plague the functioning of the Equality Courts as a whole, were encountered. ${ }^{79}$ While the Complainants in both matters were represented from the outset by the Clinic and counsel, the need for legal representation was clear. All the Complainants were asylum seekers and refugees residing in informal settlements and would have been unable to secure legal representation had it not been for the Clinic's assistance. The State, on the other hand, briefed both senior and junior counsel at great expense to the tax payers. This clearly illustrates the situation where a well resourced respondent would spare no expense thereby placing a vulnerable indigent complainant at a disadvantage were it not for pro bono legal assistance from an organisation such as the Clinic. However, given the complex evidential aspects and legal arguments which were addressed during these proceedings this matter clearly dictated the involvement of skilled litigators. For instance, in the absence of South African jurisprudence on adverse effect discrimination, it was necessary to research foreign law in order to develop an argument. It would be difficult to see how this could be accomplished without the assistance of legal representatives.

Public awareness was clearly a concern for the court in the Said matter. The judge consistently noted the need to bring the Equality Courts within the contemplation of the general public as an accessible and prominent forum and as such made numerous accommodations to the press and public. This concern from the judiciary, however, requires the support of the government, NGOs and civil society in order to overcome this challenge.

The most glaring challenge which was highlighted by these cases was the impact of the workload placed on the Equality Court clerk and the detrimental impact that this had on the effective running of the cases. From the outset the Clinic attorneys experienced difficulty with initiating and administering the cases as the representatives of the Complainants by virtue of the fact that the Cape Town High Court has only one trained Equality Court clerk, who acts in her capacity as such over and beyond her function as a clerk of the High Court and work in the High Court Certification office. In her absence no substitute was catered for and ordinary court personnel simply refused to provide any assistance as it was not their function. As a result, where the clerk of the Equality Court was not at work, or unavailable for whatever reason, the Clinic attorneys were required to make numerous trips in order to accomplish the simple task of filing documents. For the attorneys this was a time consuming and costly inconvenience, but an unrepresented, and possibly indigent complainant faced with such obstacles may well be frustrated into abandoning a good case.

This is a clear example of the overburdening of Equality Court staff, which the various commentators have identified is a key challenge. ${ }^{80}$ In practice this proved to be a serious hurdle to the proper and timeous administration of the cases and is a critical issue, which the Equality Courts must address in order to properly perform their functions. For instance, the proceedings in the Said matter, on one particular day, were set down to be heard in a court which was woefully inadequate, given the number of individuals attending the proceedings. In light of this situation it was necessary to address the court on the administrative inefficiencies of the Equality Courts. Counsel for the Complainants submissions were as follows:]

M'Lord, may I appeal to you and to those who are responsible for the functioning of [the] Equality Courts that the Equality Court matters have to [be recorded] on the court roll like any other matter. A court has to be assigned before the time like any other court matter. The clerk of the Equality Court has to ensure that she is 
present when Equality Court matters are heard. If she is absent there has to be a substitute assigned like in any other High Court matter... ${ }^{81}$

Through this address two key administrative failings are highlighted: Firstly, although the Equality Courts are specialist courts operating within the existing court structure they require the same consideration as any other court matter. Specifically, court allocation and recording of the hearing should be done in the normal course. Secondly, the Equality clerk, or her substitute, must be involved in the matter and present at court so as to ensure that the functions ascribed to the clerk by the Act and the Regulations are complied with. These two concerns could be achieved through a policy shift without necessitating structural changes to the Equality Courts. Nevertheless, the impact that this will have on the administration of cases will be an important step forward for the proper functioning of the courts. If the administrative challenges of the courts remain un-addressed, Counsel for the Complainants quite aptly submitted that: "[t]his matter has to be addressed urgently... . otherwise other prospective litigants would be reluctant to refer unfair discriminations to the Equality Court ..."82 This should further be seen in the context of the fact that the Complainants in the Said matter were represented by the Clinic and Counsel. An unrepresented complainant would face severe prejudice due to these administrative failings and, as stated by Counsel, this may act as a deterrent to individuals whose rights have been violated. It was, however, encouraging that the court did not simply dismiss these submissions out of hand. Rather the Judge stated the following:-

I will see that the deficiencies in the organisation of the court is brought to the attention of both the court manager and the Judge President. The unfortunate situation is that under normal circumstances, when the High Court sits as a High Court, the Judge sits with his personal registrar and the registrar makes all the arrangements. Unfortunately, the situation has arisen that the registrar of the Equality Court also has other functions and it seems there's room for improvement. The concern that I share with you is that the Equality Court is supposed to be a court that promotes equality and advance those values in our constitution that promotes human dignity and it is not dignified for Complainants to come to a courtroom like this, that is totally inadequate, and I need to address that and I will do that, and may I use this opportunity to apologise to the Complainants for the inconvenience that they are suffering today. ${ }^{83}$

The author hopes that the Judge's undertaking will have an impact and result in this critically needed redress of the administration of the Equality Courts. In this passage the Judge noted an institutional distinction between the Equality Courts and the ordinary courts, which if addressed could resolve many of the overburdening problems currently faced. The handing over of the administrative functions relating to the allocation of courts to each individual Judge's registrar would spread the workload. Moreover, the registrars are accustomed to making such arrangements as it is a function that they ordinarily fulfil.

\section{Concluding Remarks}

South Africa bears a legacy of inequality and struggle against oppression, the result of which has been a democratically elected government and a constitutional assertion that the Republic is now based on human dignity, the achievement of equality and the advancement of human rights. ${ }^{84}$ Within this context the Equality Courts have been heralded as a transformative mechanism for the redressing of systemic inequality and the promotion of the right to equality. Unfortunately, post-apartheid South Africa has been characterised by deep-rooted xenophobia. This widely held attitude has resulted in violent attacks on foreign nationals and in discrimination against migrants. Refugees in particular are a vulnerable category of migrants who, by virtue of the inherent nature of their condition, are unable to seek assistance from their own country or embassy. As a result they are likely to be the most prejudiced by any discriminatory action motivated by xenophobic opinions.

Despite the state's obligation to protect the people within its territory, and its obligation to provide asylum to refugees, the Clinic's clients who approached the Clinic in the aftermath of the xenophobic attacks complained of discrimination at the hands of the police. This prompted the Clinic to approach the Equality Courts to seek redress for those affected by this disheartening treatment of the migrants who have entered the Republic in search of protection.

During the course of the proceedings the Clinic attor neys experienced firsthand how the poor administration of the courts could be detrimental to a case and particularly if the litigants are unrepresented, how this may lead to the abandonment of a claim and the reluctance to utilise the courts again. The second interesting aspect which emerged during these proceedings was that of the shifting onus of proof. Given the difficulty in proving discrimination, a residual burden of proof is problematic. However, at this stage this question remains open.

As a consequence of the difficulties of proving discrimination, particularly when the events occur during a violent uprising and without clear written instructions, the Equality Court in both the Said and Osman matters were at pains to find against the Complainants but nevertheless ruled 
in favour of the state. The Clinic, however, remains of the opinion that the disparity in the services provided by the police officials to the Complainants, as opposed to the South African nationals, was motivated by xenophobic attitudes. In order to address the root cause of this pervasive problem the Clinic continues to petition the courts for relief.

Given the results in the above-reviewed matters, and the institutional challenges faced in bringing forth these equality claims, the inexorable question which remains to be answered is whether the Clinic would approach the Equality Courts again, and why? This question would be answered in the positive. Through this experience with the Equality Courts the Clinic observed several key benefits. Firstly, there was a great deal of media coverage of the cases, bringing the plight of refugees and the victims of xenophobia to the attention of the South African public. Secondly, the Equality Courts offered the Clinic's clients a notable public space to voice their grievances and also to hear the explanations offered by the police witnesses who testified in court as to the police conduct. Thirdly, the requirement by the court for the South African Human Rights Commission to provide attitudinal training to police officials will expectantly have a positive impact. Lastly, the proceedings ensured that the Police Services were held accountable and this raised a heightened sense of the care needed when handling refugees so as to avoid future liability.

\section{Notes}

1. For instance, s 39(2) of the now repealed Aliens Control Act (95 of 1991), contained the following draconic list of socalled "prohibited persons," which included: (a) any person likely to become a public charge by reason of infirmity of the mind or insufficient means; (b) any person who, from information received from a government through official or diplomatic channels, is deemed by the Minister to be an undesirable inhabitant; (c) any person who lives or has lived on the earnings of prostitution; (d) any person who has been convicted in any country of a list of offences ranging from murder to obstructing the ends of justice; (e) any mentally ill, deaf, dump or blind person; (f) any person who is afflicted with a contagious, communicable or other disease, or virus; (g)-(h) any person who has been removed from the Republic by warrant issued under any law.

2. Convention relating to the Status of Refugees, 189 U.N.T.S. 150, (entered into force 22 April 1954) [Refugee Convention].

3. Convention Governing Specific Aspects of Refugee Problems in Africa 10001 U.N.T.S. 45, (entered into force 20 June 1974).

4. In 2008 the Southern African Migration Project (SAMP) gave the following figures: '[p] rior to 1990, most authorized migrants to South Africa came from Europe and neighboring countries... . Between 1990 and 2004, a total of 110,000 legal immigrants entered the country, 27 percent of whom were from other African countries... . Since 1990, South Africa has become a new destination for refugees from the rest of Africa. According to the South African government, there were nearly 160,000 refugee claims between 1994 and $2004 \ldots$. Of these, the majority (74 percent) were from African countries. Rates of acceptance varied from country to country.... The numbers have continued to grow' (Jonathan Crush, "Country Profile: South Africa: Policy in the Face of Xenophobia," available at http://www .migrationinformation.org/Feature/display.cfm?ID=689). As at January 2012 the United Nations High Commissioner for Refugees (the UNHCR) recorded that there are currently 27,899 Refugees and 219,368 Asylum Seekers in South Africa (2012 UNHCR country operations profileSouth Africa available at http://www.unhcr.org/cgi-bin/ texis/vtx/page? page $=49 \mathrm{e} 485$ aa6\&submit $=\mathrm{GO}>$ ).

5. Jean P. Misago, Tara Polzer and Loren Landau, "Xenophobia: Violence against Foreign Nationals and other 'Outsiders" in Contemporary South Africa Migration Issue Brief 3 (June 2010), available at http:// independent.academia.edu/TaraPolzerNgwato/ Papers/247589/Xenophobia_Violence_against_Foreign_Nationals_and_other_Outsiders_in_Contemporary_South_Africa>. The Consortium for Refugees and Migrants in South Africa (CoRMSA) keeps a database of xenophobic attacks, accessed on 1 July 2012, which is available at http://www.cormsa.org.za/wp-content/ uploads/2009-/05/cormsa-database-of-violence-against -foreign-nationals.pdf.

6. Human Rights Watch, "VI. Xenophobia And Attacks against Migrants," in Report on the Situation in South Africa (March 1998), available at http://www.hrw.org/legacy/ reports98/sareport/Adv-5a.htm\#_1_49.

7. UNHCR, " 2012 UNHCR Country operations profileSouth Africa," accessed on 3 August 2012, available at http:// www.unhcr.org/cgi-bin/texis/vtx/page?page=49e485aa6.

8. Ransford Danso and David Alexander McDonald D.A. "Writing Xenophobia: Immigration and the Press in PostApartheid South Africa, " in Jonathan Crush (ed.) Migration Policy Series No. 17, Southern African Migration Project, (2000), 20.

9. The timeline of the attacks started on 12 May 2008 with a series of riots in the township of Alexandra (in the north-eastern part of Johannesburg) when locals attacked migrants. In the following weeks the violence spread, first to other settlements in the Gauteng Province, then to the coastal cities of Durban and Cape Town. At this time attacks were also reported in parts of the Southern Cape, Mpumalanga, the North West and Free State.

10. International Organization for Migration, "Towards Tolerance, Law, and Dignity: Addressing Violence against Foreign Nationals in South Africa," (February 2009), accessed on 1 July 2012, available at www.irinnews.org/ pdf/IOM_report.pdf. See further Jean P. Misago et al. 
"May 2008 Violence Against Foreign Nationals in South Africa: Understanding Causes and Evaluating Responses," April 2010 report compiled by the University of the Witwatersrand Forced Migration Studies Programme and the Consortium for Refugees and Migrants in South Africa, accessed on 1 July 2012, available at http://www.cormsa. org.za/wp-content/uploads/2009/05/may-2008-violenceagainst-foreign-nationals-in-south-africa.pdf.

11. The Clinic provides legal assistance to refugees and asylum seekers, whether documented or undocumented. In South Africa, a refugee is someone who has been granted refugee status from the Department of Home Affairs (DHA) and an asylum seeker is someone who has lodged an application for asylum with the DHA, which has not been finalised. For the purposes of this report, the term refugee shall refer to refugees or asylum seekers (undocumented or not) who have approached the Clinic for legal protection.

12. Said and others $v$ The Minister of Safety and Security and others (EC13/08), unreported judgement handed down on 7 December 2011.

13. Osman v Minister of Safety \& Security \& others [2011] JOL 27143 (WCC).

14. Act 4 of 2000.

15. Longman Dictionary of Contemporary English $3^{\text {rd }}$ ed. (2005), 1661.

16. Bronwyn Harris, "Xenophobia: A new pathology for a new South Africa?" in Hook D. \& Eagle G. (eds) Psychopathology and Social Prejudice, (Cape Town: Cape Town University Press, 2002), 170.

17. Union of Refugee Women and Others v Director: Private Security Industry Regulatory Authority and Others [2007] (4) SA 395 (CC).

18. Ibid., para 143.

19. Ibid., para 144 .

20. Ibid., at para 28 .

21. Ibid., para113.

22. Minister of Safety and Security and Another v Carmichele [2004] (3) SA 305 (SCA).

23. Ibid., para 43.

24. Act 4 of 2000 .

25. Cathi Albertyn, Beth Goldblatt and Chris Roederer (eds.), Introduction to the Promotion of Equality and Prevention of Unfair Discrimination Act, (Johannesburg, Witwatersrand University Press, 2001), 2.

26. Chapter 4 of the Equality Act.

27. The Preamble to the Equality Act provides that ' $t \mathrm{t}] \mathrm{he}$ consolidation of democracy in our country requires the eradication of social and economic inequalities, especially those that are systemic in nature, which were generated in our history by colonialism, apartheid and patriarchy, and which brought pain and suffering to the great majority of our people... . Although significant progress has been made in restructuring and transforming our society and its institutions, systemic inequalities and unfair discrimination remain deeply embedded in social structures, practices and attitudes, undermining the aspirations of our constitutional democracy... . This Act endeavours to facilitate the transition to a democratic society, united in its diversity, marked by human relations that are caring and compassionate, and guided by the principles of equality, fairness, equity, social progress, justice, human dignity and freedom.'

28. Section 1(xvii) of the Equality Act.

29. Section 16(1) of the Equality Act. Currently, the Department of Justice and Constitutional Development lists 382 courts as being designated as equality courts throughout the country. See http://www.justice.gov.za/EQC-act/eqc_ courts.html, accessed on 1 July 2012.

30. Johan De Waal and Iain Currie, The Bill of Rights Handbook $4^{\text {th }}$ ed. (Cape Town: Juta \& Co., 2001), 228.

31. Regulations 764 of 13 June 2003 (Government Gazette No. 25065), which came into operation on 16 June 2003.

32. Ibid., Regulation 10(10)(b).

33. Albertyn et al., Introduction to the Promotion of Equality.

34. Ibid., 27.

35. Narnia Bohler-Muller, "The Promise of Equality Courts," (2006) 22 South African Journal on Human Rights 380 at 396.

36. Ibid., 403.

37. Narnia Bohler-Muller "What the Equality Courts can learn from Gilligan's Ethic of Care: A Novel Approach," (2000) 16 South African Journal on Human Rights, 623 at 641.

38. Ibid., 638.

39. Ibid., 640 .

40. Judicial Service Commission and Magistrates Commission Bench Book for Equality Courts (undated), a copy of this text was obtained by the author through the University's Government Publications Department. No updates of this work have been published despite a wealth of jurisprudence which has emerged following its initial publication shortly before the coming into operation of the Equality Courts in 2003.

41. Ibid., 23.

42. Rosann Krüger, "Racism and Law: Implementing the Right to Equality in Selected South African Equality Courts," unpublished doctoral thesis, submitted at Rhodes University in December 2008, accessed on 1 July 2012, available at http://eprints.ru.ac.za/1429/1/Kruger-TR09-79.pdf, 219.

43. Lynn Smith, "Judicial Education on Context," (2005) 38 UBC Law Review 569 at 582.

44. Albertyn et al., Introduction to the Promotion of Equality, 28.

45. Ibid.

46. Section 21(2)(d) of the Equality Act.

47. Section 21(2)(e) of the Equality Act.

48. Section 21(2)(g) of the Equality Act.

49. Section 21(2)(h) of the Equality Act.

50. Section 21(2)(i) of the Equality Act.

51. Section 21(2)(1) of the Equality Act.

52. Section $21(2)(\mathrm{p})$ of the Equality Act.

53. Section 21(2)(k) of the Equality Act.

54. Section $21(2)(\mathrm{m})$ of the Equality Act. 
55. Albertyn et al., Introduction to the Promotion of Equality, 28.

56. Strydom v Nederduitse Gereformeerde Gemeente Moreleta Park [2008] JOL 22361 (T).

57. Sonke Gender Justice Network v Malema [2010] JOL 25181 (EqC, JHB).

58. Ibid., para 25.

59. Ibid., para 27.

60. See the outline of the 2008 xenophobic attacks set out at note 9 above.

61. The Constitutional Court has repeatedly affirmed that refugees are a "vulnerable category of person" in South Africa (see Larbi-odam and others $v$ Members of the Executive Council for Education 1998 (1) SA 745 (CC), para 19; and, the Union of Refugee Women and others $v$ Director: Private Security Industry Regulatory Authority and others 2007(4) SA 295 (CC), paras 28-31).

62. The Constitutional Court has confirmed that proof of intention is not a threshold requirement for either direct or indirect discrimination (Pretoria City Council $v$ Walker 1998 (2) SA 363 (CC), para 43; and President of the Republic of South Africa v Hugo 1997 (4) SA 1 (CC), para 41). This is also in keeping with the equality jurisprudence of both Canada (Ont. Human Rights Comm. v. SimpsonsSears ([1985] 2 S.C.R. 536); Andrews v. Law Society of British Columbia, [1989] 1 S.C.R. 143; and Eldridge v. British Columbia (Attorney General), ([1997] 3 S.C.R. 624)), and the European Court of Human Rights (Timishev v Russia (Application Nos. 55762/00 and 55974/00); Zarb Adami v Malta (Application No. 17209/02); Sampanis and others $v$ Greece (Application No. 32526/05)).

63. Section 21(2) of the Equality Act.

64. Said matter, para 5.

65. Ibid., paras. $15-28$.

66. Ibid., para 45.

67. Ibid., para 50 .

68. Ibid., para 51.

69. Ibid., paras 52-53.

70. Ibid., para 57.

71. Ibid., paras $66 \& 95$.

72. Distilled from the South African Human Rights Commission recommendations reproduced in the judgement at para 93.

73. Ibid., 27.
74. Ibid., p. 25. This same question of whether the onus shifts conclusively was also noted by Justice Erasmus in the Said matter at para 28.

75. Act 66 of 1995.

76. Section 192(2) of the Labour Relations Act.

77. John Grogan, Dismissal, (Cape Town: Juta Law, 2002), 91.

78. Ibid.

79. For a discussion of the challenges faced by the courts see "South African Human Rights Commission Parliamentary Equality Review Process," accessed on 1 August 2012, available at www.pmg.org.za/docs/20-06/061016SAHRC1.pdf, 14; Dana Kaersvang, "Equality Courts in South Africa: Legal Access for the Poor," The Journal of the International Institute, Spring 2008, 4; Philippa Lane, "South Africa's Equality Courts: An Early Assessment," (2005), accessed on 1 August 2012, available at http://www.csvr.org.za/wits/pap-ers/papr-ctp5.htm; PIMS-SA report, for IDASA "Equality Courts," para 2.4.4.10, accessed on 1 August 2012, available at www. idasa-.org/media/uploads/outputs/files/A\%20Report\%20 on\%20Equality\%20Courts.pdf; Krüger, "Racism and Law," 232; E. Naidu, "Equality courts are crying out for work," IOL news (April 10 2005), accessed on 1 August 2012, available at http://www.iol.co.za/news/south-africa/ equality-courts-are-crying-out-for-work-1.238411.

80. See, for instance, Krüger, "Racism and Law," 255.

81. Court Record, 24 May 2010, at p. 219, transcripts on file with the author.

82. Court Record, 24 May 2010, at p. 219-20, transcripts on file with the author.

83. Court Record, 24 May 2010, at p. 221, transcripts on file with the author.

84. The Founding Provision set out in s 1 of the Constitution (Act 108 of 1996).

Justin de Jager is an attorney of the High Court of South Africa working primarily in the Refugee Rights Unit's strategic litigation. He has completed courses in Advanced Refugee Law and Statelessness at the American University of Cairo and Oxford.

I wish to express my thanks to Tal Schreier for her guidance and insight during the writing of this paper. 